\title{
Література:
}

1. Improving environment and health in Europe: how far have we gotten? Copenhagen: World Health Organization. Regional Office for Europe, 2015. 134 p.

2. Лапенко А.О. Особливості негативного впливу нафтогазової промисловості на навколишне середовище. Вісник СумДУ. Серія Економіка. 2010. № 2. С.41-47.

3. Шабаров Ю.С. Органическая химия: Часть 2. Циклические соединения. М.: Химия, 1994. 848c.

4. Mottaleb M.A., Littlejohn D. Application of an HPLC-FTIR modified thermospray interface for analysis of dye samples. Analytical Sciences. 2001. № 17. C. 429-434.

DOI https://doi.org/10.30525/978-9934-26-183-1-14

\section{GLOBOROTALIA MENARDII (D'ORBIGNY, 1826) PARKER, JONES \& BRADY, 1865 IN SECTIONS OF THE MIOCENE OF PODILLYA (WESTERN UKRAINE)}

\author{
Tuzyak Ya. M. \\ Candidate of Geological Sciences, \\ Head of Paleontological museum \\ Ivan Franko National University of Lviv \\ Lviv, Ukraine
}

For the first time, a microfaunistic analysis of Miocene formations in Podillya (Western Ukraine) revealed planktonic forms of foraminifera belonging to the globorotaliid family. They are represented by Globorotalia menardii taxa with morphological varieties of two generations.

The name Globorotalia menardii combines a group of tropical planktonic foraminifera, rapidly evolving over the past 16-12 Ma [2], found in marine sediments of the Middle Miocene and up to modern sediments, characterized by a wide distribution range and a variety of forms. At the present stage, they are found in the Neogene formations of the regions belonging to the Paratethys, Mediterranean basins, as well as in the Pacific, Indian and Antlantic oceans. G. menardii is valuable for evolutionary, biostratigraphic, paleoecological and paleogeographic constructions. From the point of view of evolutionary development, Neogene menardiform globorotalids are unique 
objects of study for tracing morphological speciation in planktonic foraminifera with fixation of ancestral and hereditary forms. From the position of biostratigraphy - a biomarker for determining the stratigraphic position of deposits in the International Chronostratigraphic Scale. From the point of view of paleoecology - as a special material clarifying the laws of changing morphological features depending on the change of environmental factors. From the point of view of paleogeography - as an ideal indicator of environmental conditions, since it is a species that lives in temperate, tropical and subtropical conditions.

Material. The research is based on actual material collected during the 2016 field expedition within the village Vanzhuliv, Ternopil region. Samples of rocks and containing fossils are selected from accumulative terrigenous (sandy) stratum with a large amount of organogenic-detritus material (corals, bivalves, gastropods, scaphopods, bryozoans). At the same time, with rich macrofossils complexes, a variety of microfossils (ostracods, uvenil forms of bivalves, gastropods) of different systematic composition of the mixed type were discovered. A detailed study proved the Early Sarmatian age of sediments, which, according to the local stratigraphic nomenclature and classification, belong to the Buhliv beds of the Miocene, formed under the conditions of the fore-reef facies [3, 4].

Theoretical and experimental studies (microfossils analysis) contributed to the following conclusions:

1. For the first time in the Miocene sediments of the Podillya territory (Western Ukraine), a tropical plankton species Globorotalia menardii (d'Orbigny, 1826) Parker, Jones \& Brady, 1865 was discovered.

2. Globorotalia menardii is represented by taxa of two generations with various morphological features (Fig. 1-4): Late Badenian - large test $(0,65$ $\mathrm{mm}$ ), with more number of chambers in the final whorl (9-11), non-keel, translucent wall; Early Sarmatian - a small size $(0.47 \mathrm{~mm})$, with a smaller quantity of chambers in the final whorl $(6-7,5)$, with a keel equipped, spikes, the wall is opaque [1].

3. The event in the evolution of menardiforms is diachronous in time. Its beginning falls on the Late Badenian-Early Sarmatian in Paratethys, in the Mediterranean it covers Serravallian-Messinian and, respectively, in the Pacific, Indian and Atlantic oceans, it corresponds to the time interval of the upper part of the Middle Miocene-Pliocene-Pleistocene. So, the nucleus of the emergence of menardiforms should be considered Paratethys (the residual marine basin of the ocean Tethys), in which their first representatives could appear. As a result of its closure, with the emergence of the Pacific, Indian, Atlantic oceans and the existence of connecting (migration) routes, these 
forms migrated to other reservoirs, where they evolved depending on environmental conditions and their duration. Accordingly, the model of development of menardiforms in each specific region will differ both in the type of taxa and the time of their change, which depended on the duration or rapid change in environmental conditions. Also, evolution could come not only from one type of taxon, but from its different representatives, which already existed within the Mediterranean. In our opinion, these circumstances have complicated the solution of issues of taxonomy, nomenclature and phylogeny of this type.

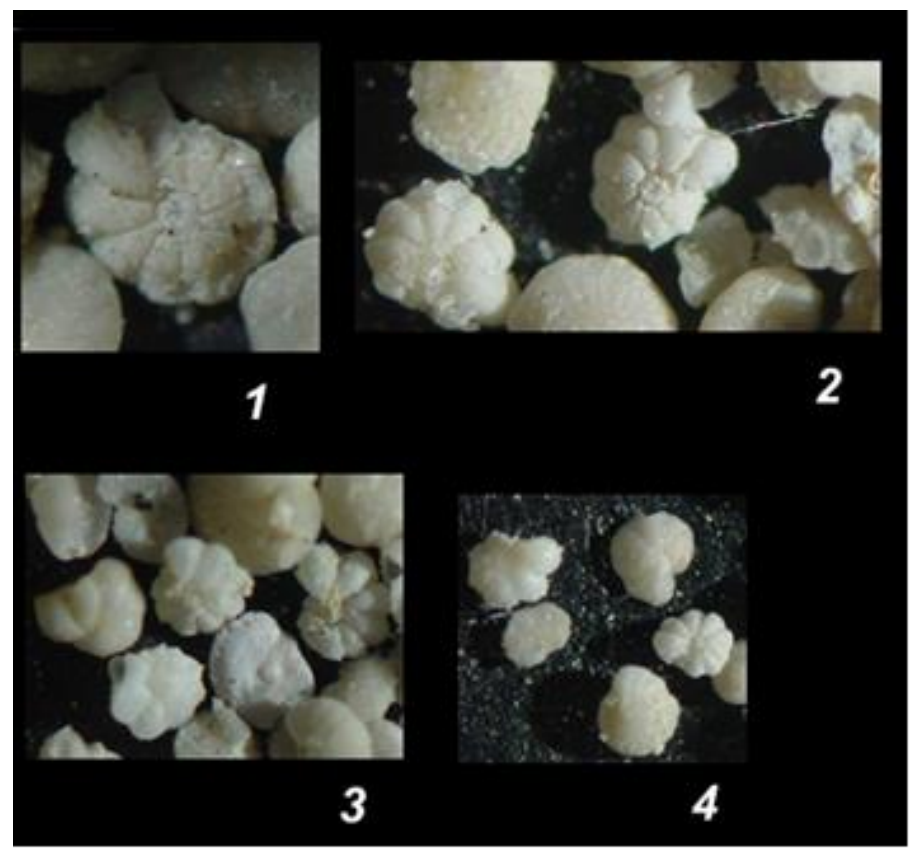

Fig. 1-4. Globorotalia menardii (d'Orbigny, 1826) Parker, Jones, Brady, 1865: $1-4$ - umbilical side view; 3 - view from the dorsal (spiral) side. 1-3 - Late Badenian forms; 4 - Early Sarmatian forms. Early Sarmatian, Miocene, Neogene, Vanzhulev, Ternopil region., Podillya, Western Ukraine.

4. So, we believe that the reference taxon and its derivatives (evolutionary forms), the holotype (lectotype, neotype) should come from Middle Miocene 
sections of the Mediterranean or possibly other regions of Paratethys, since these territories contain the first manifestations of the forms, which is an important aspect in biostratigraphy. These should be continuous sections (if possible), with clear references (geographical coordinates of clips with a detailed description of rock layers and selection of fossil organisms).

Acknowledgement. The research was carried out as a result of cooperation between the geology faculty of Ivan Franko National University of Lviv and the Institute of Geological Sciences of PAN (Krakow, Poland). The author is grateful to P. Gedl, Doctor of Geological Sciences for his cooperation and assistance in conducting research.

\section{References:}

1. Тузяк Я. Globorotalia menardii (d'Orbigny, 1826) Parker, Jones \& Brady, 1865 (планктонні форамініфери, міоцен, поділля): історія та сучасний стан (коментарі до таксономії, номенклатури і філогенії) // Палеонтол. зб. 2020. № 52. С. 23-36.

2. Kennet J.P., Srinivasan M.S. Neogene planktonic foraminifera. A phylogenetic atlas. Hutchinson Ross Publishing Company. Stroudsburg, Pennsylvania. 1983. 265 p.

3. Tuzyak Ya. Buhliv beds (Neogene, Miocene) of the Podillya (Western Ukraine): micropaleontological, stratigraphical, facial, paleoecological, paleogeographical diagnostic criteria and formation conditions. Actual problems of natural sciences: modern scientific discussions: Collective monograph. Riga: Izdevniecība «Baltija Publishing». 2020a. P. 526-581.

4. Tuzyak Ya. Buhlovian foraminiferal assemblages (Miocene, Neogene) of Western Ukraine (Podillya): taxonomic composition, paleoecology, paleogeography. The 7th International scientific and practical conference "Scientific achievements of modern society» (March 4-6, 2020). Cognum Publishing House, Liverpool, United Kingdom. 2020b. P. 225-235. 